\section{Cucumber Population WI 6383 and Derived Inbreds WI 5098 and WI 5551}

\author{
Jack E. Staub ${ }^{1}$, Clinton E. Peterson ${ }^{2}$, Linda K. Crubaugh ${ }^{3}$, and \\ Mary J. Palmer ${ }^{4}$ \\ Vegetable Crops Research, U.S. Department of Agriculture, Agricultural \\ Research Service, Department of Horticulture, University of Wisconsin, \\ Madison, WI 53706
}

Additional index words. Cucumis sativus, multiple fruiting, multiple disease resistance, exotic germplasm, vegetable breeding

A gynoecious, multiple-disease-resistant, white-spined cucumber (Cucumis sativus L.) germplasm pool Wisconsin 6383 (WI 6383) and derived inbred lines WI 5098 and WI 5.551 was released in Sept. 1990 by the U.S. Dept. of Agriculture, Agricultural Research Service (USDA/ARS). WI 6383 was made available to U.S. cucumber breeders to supply a source from which they may extract multiple-disease-resistant (MDR; greenhouse seedling tests) lines with a multiple lateral (ML) and sequential fruiting (SF) habit suitable for use in hybrid production or line development. WI 5098 and WI 5551 are gynoecious, MDR, and possess an ML and SF habit with a day-neutral flowering photoperiodism adapted to Wisconsin conditions.

\section{Origin}

WI 6383 originated from a cross between commercially adapted and exotic germplasm. The C. sativus var. sativus L. fourway cross $($ WI $1606 \times$ WI 1589) $\times($ WI 1983 $\times$ WI 1895), which was released by the USDA/ARS as WI 2843 (Peterson et al., 1985), was crossed to an F, between two C. sativus var. hardwickii (R.) Alef. plant introductions (PI 183967 and PI 215589; Fig. 1).

The four inbred $C$. sativus var. sativus components of WI 2843 resulted from efforts to establish multiple disease resistance while maintaining variability for horticulturally acceptable fruit characteristics. They were selected because of diversity in origin and variability in fruit type. Although the pedigrees of those inbred lines are complex (Fig. 1), it is possible to trace each parent to orig inal sources of disease resistance and other fruit and vine characteristics. Their paren-

Received for publication 21 Jan. 1992. Accepted for publication 31 July 1992. Mention of a trademark, proprietary product, or vendor does not constitute a guarantee or warranty of the product by the U.S. Dept. of Agriculture and does not imply its approval to the exclusion of the other products or vendors that may also be suitable. The cost of publishing this paper was defrayed in part by the payment of page charges. Under postal regulations, this paper therefore must be hereby marked advertisement solely to indicate this fact.

'Research Horticulturist and Associate Professor. ${ }^{2}$ Research Horticulturist and Professor (deceased). Research Technician.

${ }^{4}$ Specialist, Dept. of Horticulture. tage is typically derived from Gy14 with resistance to anthracnose [ Colletotrichum

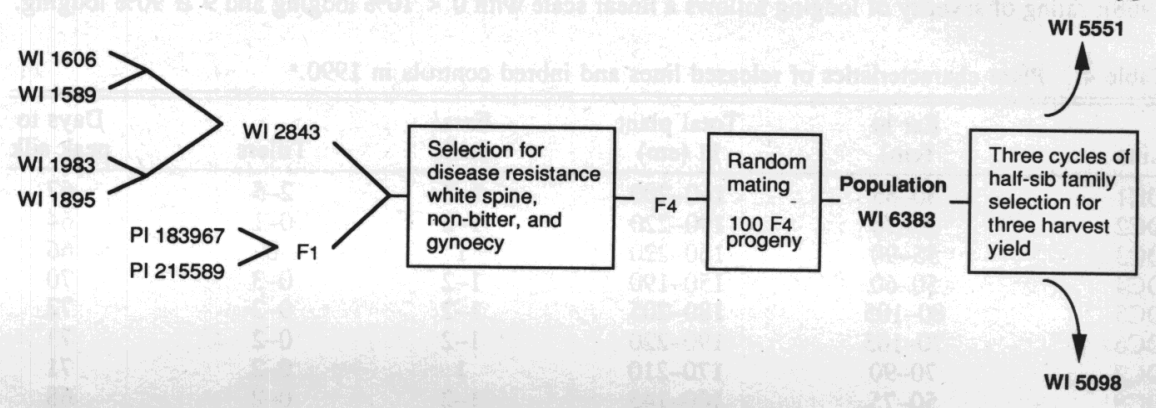

Fig. 1. Pedigree of cucumber population WI 6383 and derived inbreds WI 5098 and WI 5551.

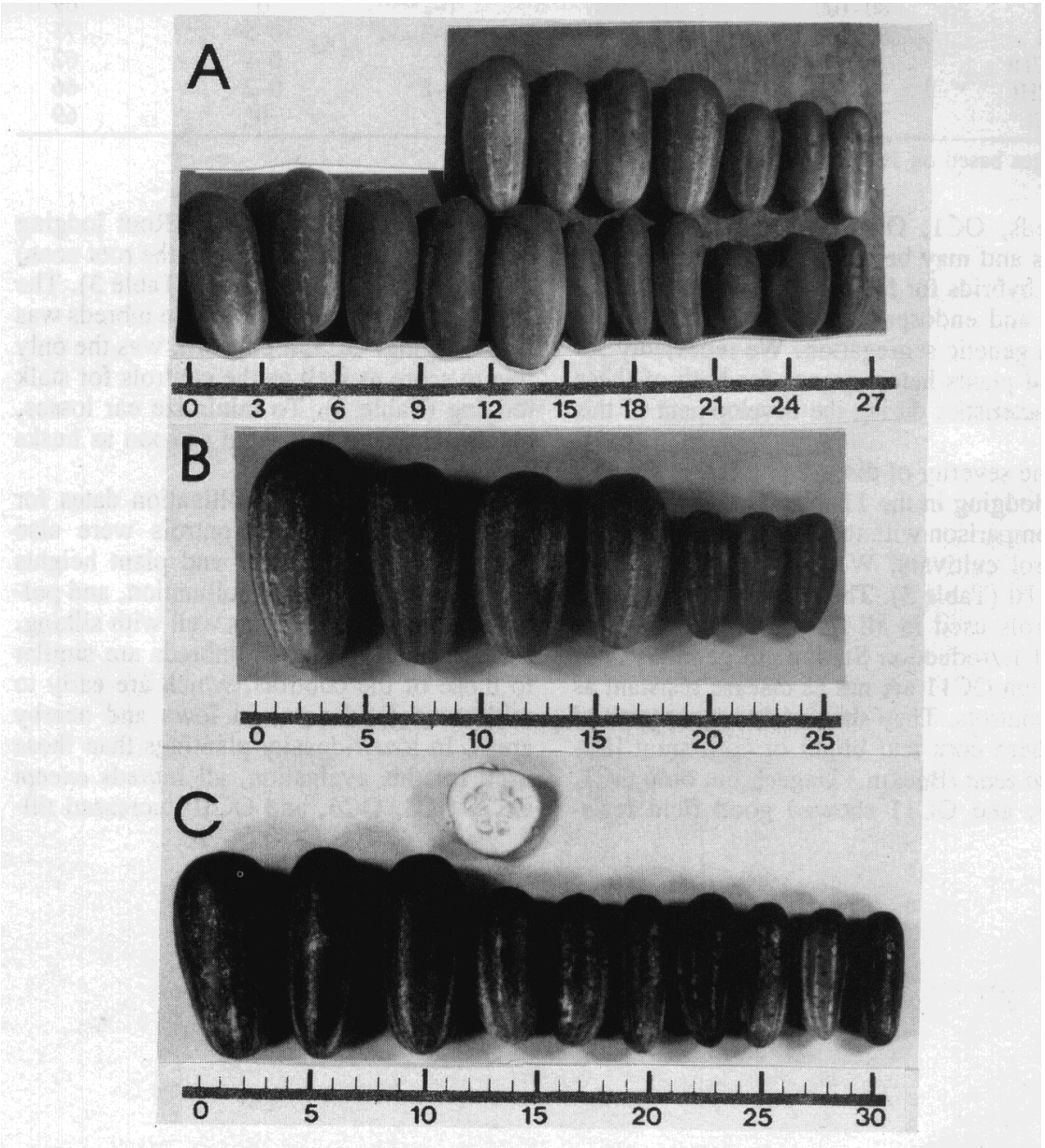

Fig. 2. Fruit of cucumber population WI 6383 [(A) (C. sativus $\times$ C. hardwickii) $\mathrm{F}_{4}$ mass] and derived inbreds WI 5098 (B) and WI 5551 (C) harvested 48 days after planting at Hancock, Wis. Scale = centimeters. lagenarium (Ross.) Ellis \& Halst], downy mildew [Pseudoperonospora cubensis (Berk. $\&$ Curt.) Rostow], and powdery mildew [Sphaerotheca fuliginea (Schl. ex Fr.) Poll.] from PI 197087. Additional introduced sources of resistance are PI 212233 (powdery mildew), Wisconsin SMR-18 [CMV, scab; Cladosporium cucumerinum Ellis \& Arthur, and fusarium; Fusarium oxysporum (Schlecht.) Synd. \& Hans f. sp. cucumerinum Gwen] and Chinese Long and Tokyo Long Green (fusarium). Gynoecious flowering habit was introduced from PI 220860, parththenocarpy from the Dutch glasshouse cucumber 'Spotvrige' and nonbitter from Dutch accession, ILG 58049.

The $C$. sativus var. hardwickii accessions were selected for ML and SF habit (Kupper 
and Staub, 1988). These accessions lack apical dominance and thus produce more and longer lateral branches than $C$. sativus var. sativus. They are short-day plants and produce small (4 to $8 \mathrm{~cm}$ long), ellipsoid fruits with large seed cells, tough skin, black spines, and bitter taste.

Progeny of the initial four-way $\times \mathrm{F}_{1}$ cross were self- or sib-pollinated for four generations, during which individuals were selected for disease resistance (as listed above), white spine, nonbitter, and gynoecious characteristics. About $100 \mathrm{~F}_{4}$, individuals were randomly mated to produce the population WI 6383 that is homozygous for resistance, white spine, nonbitter, and indeterminate traits.

Seed of $\approx 500 \mathrm{~F}_{4}$ individuals from the $\mathrm{F}_{4}$ mass were sown $91 \mathrm{~cm}$ apart in rows that were on $1.5-\mathrm{m}$ centers and subjected to three cycles of recurrent half-sib family selection (10\% selection intensity) for three-harvest fruit yield (fruit count in three harvests). Self-pollination of selected cycle 3 plants led to F, families that were evaluated in replicated trials under various spacings (Staub. 1985). The highest-yielding families were designated WI 5098 and WI 5551.

\section{Plant and fruit description}

Plants of WI 6383 are vigorous compared with 'Calypso' or 'Endeavor', possess a ML, SF habit, and are predominantly gynoecious. Fruit are bitter-free (bibi), coarse to fine, white spined, with a blocky to a slightly tapered blossom end (Fig. 2A). Fruit vary in length : diameter ratio from 2.1 to 2.6 (mean of 'Calypso' = 2.8), and seed cavity : fruit diameter ratio ranges from 0.63 to 0.54 (mean of 'Calypso' = 0.54) (Staub and Fredrick, 1988). Fruit firmness, as measured by a punch test at the stem end with a Magness-Taylor pressure tester $(0.79-\mathrm{cm}$ tip size), ranges from 19.0 to 22.5 (mean of 'Calypso' = 23.3).

Fruit yields of WI 5098 and WI 5551 (Fig. $2 \mathrm{~B}$ and C, respectively) are $37 \%$ to $51 \%$ higher than commercially adapted germplasm (Fredrick and Staub, 1989; Staub, 1985). The combining ability of WI 5098 and WI 5551 for fruit yield as evaluated in $\mathrm{F}_{1}$ combination with commercially adapted inbred lines indicates that further selection within these high-performance $C$. sativus var. sativus $\times$ var. hardwickii derivatives for fruit shape will produce lines that perform well at a high planting density $(58,000$ plants/ha) when crossed with $C$. sativus var. sativus 'lines having good general combining ability (Fredrick and Staub, 1989).

\section{Availability}

Seed of WI 6383, WI 5098, and WI 5551 from hand-pollinated greenhouse increases may be obtained from J.E.S.

\section{Literature Cited}

Fredrick, L.R. and J.E. Staub. 1989. Combining ability analysis and evaluation of nearly homozygous lines derived from Cucumis sativus var. hardwickii (R.) Alef. J. Amer. Soc. Hort. Sci. 114:332-338
Kupper, R.S. and J.E. Staub. 1988. Combining ability between lines of Cucumis sativus L. and Cucumis sativus var. hardwickii (R.) Alef. Euphytica 38:197-120.

Peterson, C.E., J.E. Staub, M.J. Palmer, and L. Crubaugh. 1985. Wisconsin 2843, a multiple disease resistant cucumber population. HortScience 20:309-310.
Staub, J.E. 1985. Preliminary evaluation of inbred lines derived from Cucumis sativus var. hardwickii (R.) Kitamura. Cucurbit Gen. Coop. Rpt. 8:18-21.

Staub, J.E. and L.R. Fredrick. 1988. Evaluation of fruit quality in Cucumis sativus var. hardwickii (R.) Alef-derived lines. Cucurbit Gen. Coop. Rpt. 11:25-28. 